\title{
Secondary pollen presentation and floral traits of Heliconia psittacorum ${ }^{(1)}$
}

\author{
TALITA OLIVEIRA NASCIMENTO(2), PATRÍCIA CAMPOS SILVA(2), VIVIAN LOGES(3), SANDRA MARIOTTO(4), \\ WILLIAN KRAUSE ${ }^{(2)}$, CELICE ALEXANDRE SILVA ${ }^{(2)^{*}}$
}

\begin{abstract}
The secondary presentation of pollen consists of a floral mechanism where the presentation of pollen occurs in other floral structures in addition to the anther, in order to increase the precision of the dispersion of the pollen by the vectors. This study aims to describe the temporal dynamics of secondary pollen presentation, and morphological and morphometric characteristics in stages of preanthesis and anthesis in genotypes of five natural Heliconia psittacorum populations. For the study of floral morphometry traits of length of the flower, stamen, stigma and height of filament insertion in the petal in bud and flower were measured. The floral morphology of pre-anthesis buds and flowers in anthesis, the presence or absence of characteristics such as herkogamy, region of filament insertion in the petal, region of stylar hairs, and of secondary pollen deposition were evaluated. Treatments of controlled pollinations, self-pollination, geitonogamy, cross-pollination, natural pollination and growth to pollen tube were sampled. Floral herkogamy and pollen transfer to the adhered hairs in the stylar region were clearly observed during anthesis, constituting the first record of occurrence of secondary pollen presentation in Heliconiaceae. Pollen tube growth was inhibited in the stigmatic, style and basal regions of the pistil. Natural fruiting produced little or no fruit. The positioning of the stamens above the stigma, pollen viability and stigma receptivity during anthesis of $H$. psittacorum flowers may favor self-pollination. The stylar hairs observed in all H. psittacorum populations' help in the retention of pollen grains. The low fruiting rate in controlled and natural pollinations suggest that the main propagation form of $H$. psittacorum in the study areas is based on asexual reproduction.
\end{abstract}

Keywords: Heliconiaceae, floral biology, floral morphology, stylar hairs, pollination.

\section{RESUMO}

Apresentação secundária de pólen e características florais de Heliconia psittacorum

A apresentação secundária de pólen consiste em um mecanismo floral onde a apresentação de pólen se dá em outras estruturas florais além da antera, a fim de aumentar a precisão da dispersão do pólen pelos vetores. Este estudo teve como objetivo descrever a dinâmica temporal da apresentação secundária de pólen e as características morfológicas e morfométricas nos estádios de préantese e antese, em genótipos oriundos de cinco populações naturais de H. psittacorum, na região centro-oeste do Brasil. Para o estudo das características da morfometria floral foram avaliados comprimento da flor, altura do estigma e da inserção do filamento do estame na pétala. A morfologia floral dos botões em pré-antese e das floresforam avaliadas quanto à presença ou ausência d características como hercogamia, forma da inserção do filamento do estame na pétala, região de pelos estilares e de deposição secundária de pólen. Tratamentos de polinizações controladas, tais como: autopolinização, geitonogamia, polinização cruzada e polinização natural e crescimento do tubo polínico foram realizados. A hercogamia floral e a transferência de pólen para os pelos aderidos na região estilar foram claramente observados durante a antese, constituindo o primeiro registro de ocorrência de apresentação secundária de pólen em Heliconiaceae. O crescimento do tubo polínico foi inibido na região estigmatica, estilete e base do pistilo. O posicionamento dos estames acima do estigma, a viabilidade do pólen e a receptividade do estigma durante a antese de flores de $H$. psittacorum podem favorecer a autopolinização. A presença de tricomas no estilete auxilia na retenção de grãos de pólen. A baixa taxa de frutificação em polinizações controladas e naturais sugere que a principal forma de propagação de H. psittacorum nas áreas de estudo é baseada na reprodução assexuada.

Palavras-chave: Heliconiaceae, biologia floral, morfologia floral, tricoma estilar, polinização.

\section{INTRODUCTION}

In some plant species, pollen is present in other floral structures aside from the anthers, either by simple deposition or by special expulsion mechanisms, causing the pollen to contact other floral parts. This mechanism, known as secondary pollen presentation (CASTRO et al., 2008; ERBAR and LEINS, 2015), has traditionally been described as a mechanism that increases the efficiency and precision of pollen reception and/or donation, thus increasing male and/or female plant fitness (LLOYD and YATES, 1982). Secondary pollen presentation mechanisms

\footnotetext{
DOI: http://dx.doi.org/10.14295/oh.v24i4.1227

(1) Received in 19/05/2018 and accepted in 07/11/2018

(2) Universidade do Estado de Mato Grosso, Tangará da Serra-MT, Brazil. *Corresponding author: celice@unemat.br

(3) Universidade Federal Rural de Pernambuco, Recife-PE, Brazil.

(4) Instituto Federal de Mato Grosso, Cuiabá-MT, Brazil.

Licensed by CC BY 4.0
} 
are highly variable among Angiosperms, usually associated to the style or stigma areas, involving hairs or growth of the stylar tissue (LADD, 1994; LEINS and ERBAR, 2010).

The Heliconiaceae family is represented by a single genus, Heliconia. Considering the 29 species that occur in Brazil, they are distributed from the Midwest to the North, Northeast and Southeast regions (BRAGA, 2014). Heliconia spp. has terminal and long-lived inflorescences, flowering during most of the year. The interior of each bract can contain a varied number of flowers (CASTRO et al., 2011). The flowers are bisexual, open at daybreak and usually drop in the late afternoon of the same day (CRUZ et al., 2006). The pollen grains are round in polar view and concave and asymmetrical in lateral view, and the exine is restricted to small spicules (KRESS, 1985).

Heliconiaceae species reproduction occurs asexual by the growth of new shoots from the rhizome and sexualy reproduction by seeds (COSTA et al., 2011). Studies indicate that the Heliconia species of Central America are self-compatible (ENDRESS, 1994), but although they are constantly visited by pollinators, fruit and seed production are very low, indicating some degree of incompatibility during pollen tube development (BRUNA et al., 2004; MELÉNDEZ-ACKERMAN et al., 2008). Self-incompatibility has been found in many families with a high ornamental value, such as Solanaceae, Rosaceae, Brassicaceae, Asteraceae and Convolvulaceae (WANG et al., 2014)

We investigated the temporal dynamics of secondary pollen presentation and stigma receptivity in Heliconia psittacorum genotypes. More specifically, we investigated in detail (i) the morphology, morphometry and floral biology in pre-anthesis and anthesis; (ii) functionality of stylar hairs as organs of secondary pollen presentation; (iii) viability of stigma receptivity; (iv) the different sites of incompatibility reaction with pollen tube growth during anthesis and, (v) fruit formation under natural conditions.

\section{MATERIAL AND METHODS}

\section{Study Sites}

The study investigated plants of five $H$. psittacorum genotypes of natural populations were grown in the Active Germplasm Bank of the State University of Mato GrossoUNEMAT, (14 $39^{\prime} \mathrm{S}, 57^{\circ} 15^{\prime} \mathrm{W}$; $321 \mathrm{~m}$ higher). The region has a tropical climate, with a dry season between May and September and a rainy season from October to April, and a mean annual rainfall of 1,830 $\mathrm{mm}$ (DALLACORT et al., 2011). The soil is classified as a Dystroferric Red Latosol with a clayey texture and flat to gently undulating relief (EMBRAPA, 2006).

The genotypes were collected from natural populations in the counties of Barra do Bugres ( $\left.15^{\circ} 07^{\prime} 46^{\prime \prime} \mathrm{S}, 5^{\circ} 04^{\prime} 34^{\prime \prime} \mathrm{W}\right)$,

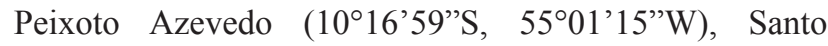

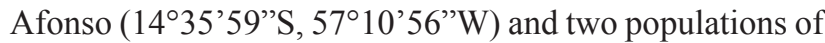
the county of Porto Estrela $\left(15^{\circ} 18^{\prime} 51^{\prime \prime S}, 15^{\circ} 18^{\prime} 51^{\prime \prime} \mathrm{W}\right.$; and $15^{\circ} 24^{\prime} 02^{\prime}$ 'S , 57¹1'51'W)

\section{Morphometry and floral morphology}

For the study of floral morphometry, five flower buds were used in pre-anthesis and five flowers in anthesis, with four replications, resulting in a total of 20 flower buds and 20 flowers per genotypes.

The following traits of each bud and flower were measured: lenght of the flower without ovary; filament insertion height in the petal and height of stigma and stamen (measured from the filament insertion in the corolla to the anther apex). The lenght of the flower in anthesis was measured from the corolla base to the apex of the exposed anthers.

The floral morphology and morphometry of preanthesis buds and flowers in anthesis were evaluated during the day, in the period of 07 and $18 \mathrm{hs}$. The presence or absence of characteristics such as herkogamy, loop in the region of filament insertion in the petal, region of stylar hairs, and of secondary pollen deposition, were recorded in the laboratory.

\section{Anthesis, pollen viability and stigma receptivity}

Floral anthesis was observed in 50 flowers of five populations of $H$. psittacorum, during seven consecutive days, from the beginning of flower opening to senescence, characterized by loss of brightness, darkening and flower drop.

For the determination of the pollen viability, ten floral buds and ten flowers in anthesis, previously bagged, were collected. Buds and flowers in all populations were evaluated every two hours between 07 and $11 \mathrm{hs}$. Ten slides were mounted per sampling time and flower stage. The pollen grains were stained with acetic carmine and counted up to 200 grains per slide with an optical microscope. Stigma receptivity was evaluated in the same 50 flowers and flower buds with $3 \%$ hydrogen peroxide $\left(\mathrm{H}_{2} \mathrm{O}_{2}\right)$ solution, being considered receptive the stigmas that formed bubbles in their stigmatic surface and nonreceptive ones without this characteristic (KEARNS and INOUYE, 1993).

\section{Reproductive system}

Controlled in vivo pollinations were performed between 07 and $10 \mathrm{~h}$, in 20 flowers per population. Since many Heliconia species are primarily self-compatible (Kress 1983), the flowers had to be emasculated before the manual pollination treatments were initiated. In previously bagged inflorescences, the identified flowers were pollinated and the inflorescence bagged in organza fabric bags again. Spontaneous self-pollination (floral pedicel was marked and the ovarian development monitored), geitonogamy (pollen between flowers of the same plant was transferred), cross-pollination (pollen between flowers of different populations was transferred) and natural pollination (five inflorescences per population were sampled, to count the number of bracts per inflorescence, number of flowers per inflorescence and number of developed fruits) were tested. 


\section{Pollen tube growth}

In order to identify the sites of incompatibility reaction to pollen tube growth in the style, the same manual in vivo pollination treatments were performed in another 20 flowers per population. After $24 \mathrm{~h}$, the styles that had been abscised normally with the perianth were collected and fixed in FAA (formaldehyde, alcohol and acetic acid) for approximately $36 \mathrm{~h}$ and transferred to $70 \%$ alcohol, where they were stored until preparing the slides.

To prepare the slides, the pistils were rinsed thrice in distilled water and treated with sodium hydroxide (NAOH $8 \mathrm{~N}$ ) in a heating mantle at $60{ }^{\circ} \mathrm{C}$ for $20 \mathrm{~min}$ to soften the stylar tissue and allow adequate penetration of the dye. The softened pistils were rinsed again and placed in petri dishes with distilled water for $1 \mathrm{~h}$. Thereafter, the pistils were plated and stained with $0.1 \%$ aniline blue solution at $0.1 \mathrm{~mol} \mathrm{~L}^{-1} \mathrm{~K}_{3} \mathrm{PO}_{3}$ (potassium phosphite) for approximately $48 \mathrm{~h}$, as described by Martin (1959), Souza et al. (2007) and Meléndez-Ackerman et al. (2008), with adaptations. The pollen tube growth was visualized under a fluorescence microscope (Olympus BX 51, wavelength $=365 \mathrm{~nm}$ ).

\section{Data analysis}

The floral morphometry was evaluated in the Shapiro Wilk test to verify the normality of the residues and the KruskalWallis test to detect any differences between the floral stages (pre-anthesis and anthesis) and the variables. To identify the morphometric differences among populations, the Scott Knott test was performed at 5\% probability, using Program $\mathrm{R}$ version 3.3.1. (R DEVELOPMENT CORE TEAM, 2014).

\section{RESULTS}

\section{Morphology and floral morphometry}

The floral anthesis of the evaluated $H$. psittacorum populations lasted from 10 to $15 \mathrm{~h}$. It began between 02 and $06 \mathrm{~h}$ to morning with a variation range of approximately one hour between populations.

The anthesis is characterized by the opening of the lateral sepal, exposure of the reproductive structures (Figures 1A and B) and pollen release from the anthers. Although the stigma is already receptive and there is no clear herkogamy in pre-anthesis, the possibility of self-pollination in this stage is zero, since the anthers are still closed (Figure 1C).

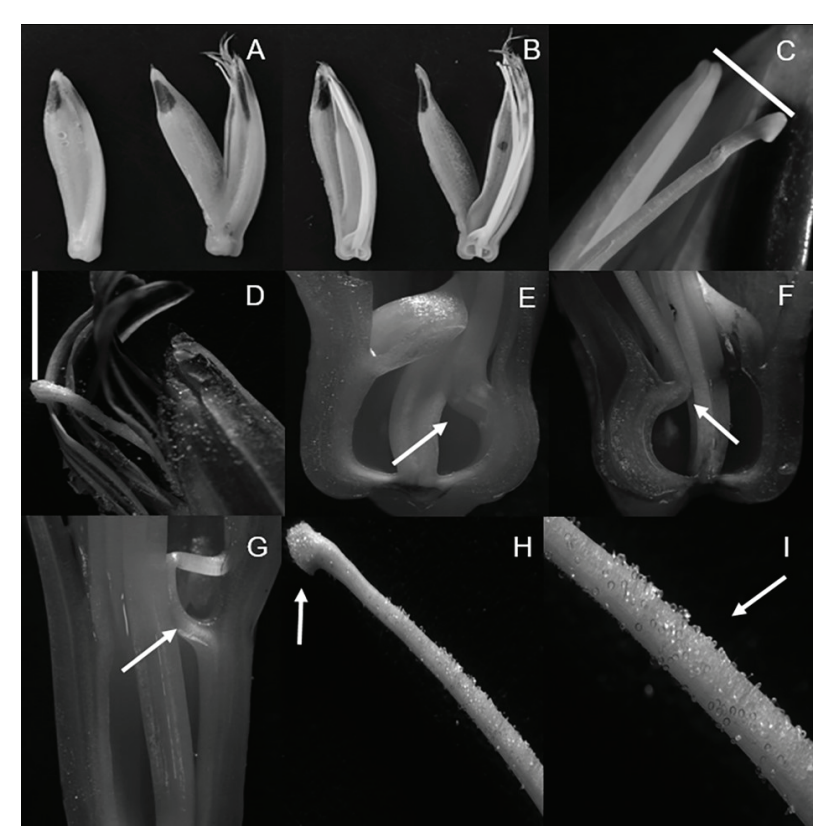

Figure 1. Internal and external morphology of flower buds and flowers of Heliconia psittacorum: A and B - Internal and external morphology of buds and flowers in pre-anthesis and anthesis; C - Stigma and anther position in pre-anthesis; D - Herkogamy of stigma and anther in anthesis; E and G - Insertion loop of the filament in the petal in pre-anthesis and anthesis; $\mathrm{H}$ - Pollen deposition in the stigma region during anthesis; I - Secondary pollen deposition on the style. $B a r=2 \mathrm{~cm}$

Floral herkogamy is evidenced during anthesis, where the stamens are positioned above the stigma (Figure 1D). The insertion of the filament into the petals forms a curvature (filament loop), observed both in pre-anthesis and anthesis (Figures 1 E-G). The initial hypothesis that the herkogamy observed in anthesis could occur due to the stretching of the loop during flower opening, as observed in $H$. wagneriana (GANON et al., 2017), was 
not confirmed in this study, because the morphology of the filament loop is equal in both floral stages. The opening of the anthers and pollen grain release occur during anthesis. The released pollen is deposited on the stigma (Figure $1 \mathrm{H}$ ) and in the stylar region (Figure $1 \mathrm{I}$ ). The presence of pollen grains in the style constitutes the first record of occurrence of secondary pollen deposition in Heliconiaceae.

In all studied populations, the pistils had hairs in the stylar region and close to the stigma. Although they were not measured, the hairs differed between populations in density and size (Figures 2A - E).

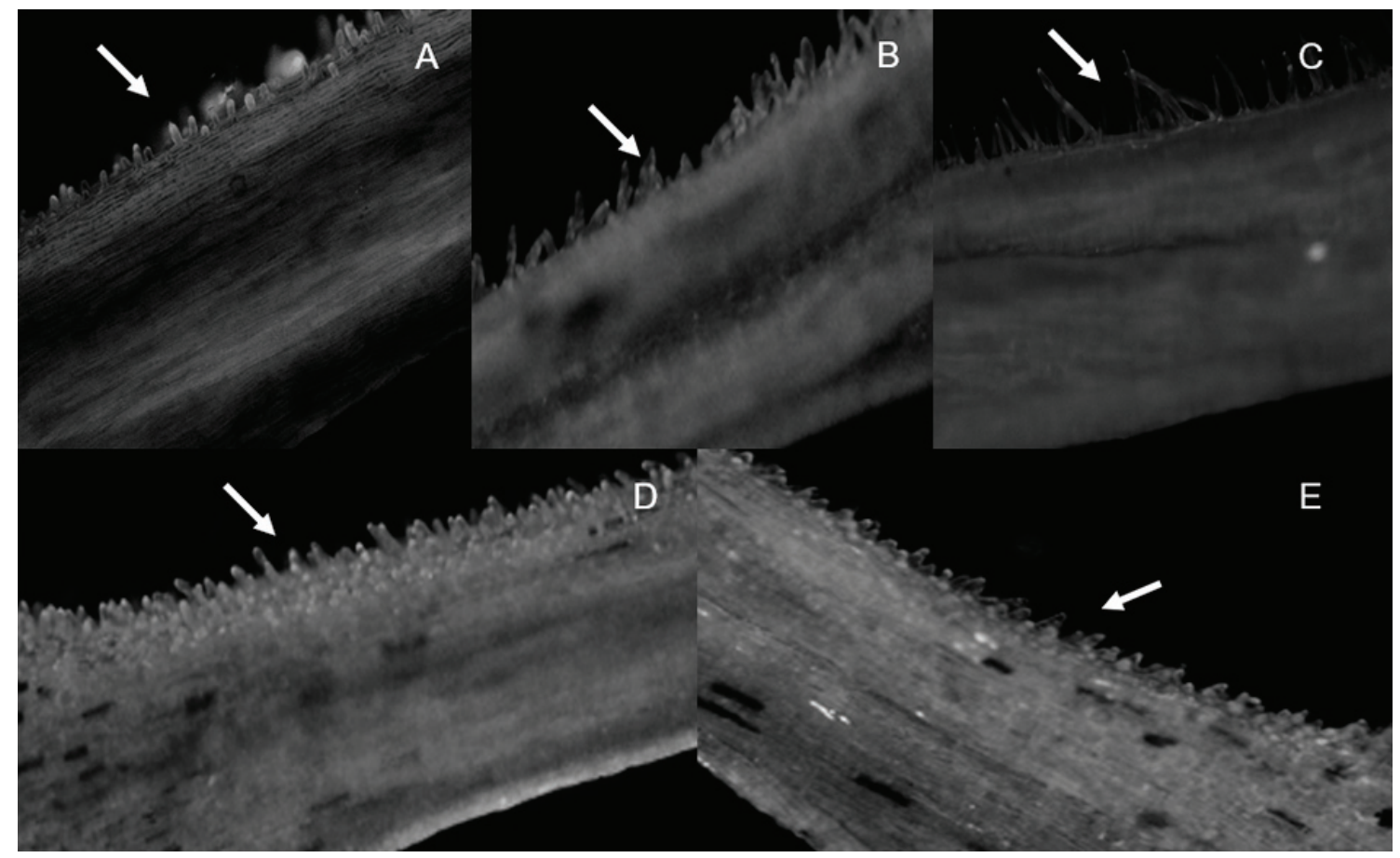

Figure 2. Details of morphology of the stylar region near the stigma of Heliconia psittacorum genotypes.

Table 1. Flower morphometry (mean \pm SD) of five natural Heliconia psittacorum populations

\begin{tabular}{|c|c|c|c|c|}
\hline Sampling site & $\begin{array}{c}\text { FH }(\mathbf{m m}) \\
\pm \text { SD }\end{array}$ & $\begin{array}{c}\text { FIH }(\mathbf{m m}) \\
\pm \text { SD }\end{array}$ & $\begin{array}{c}\text { StH }(\mathbf{m m}) \\
\pm \text { SD }\end{array}$ & $\begin{array}{c}\text { SSH }(\mathbf{m m}) \\
\pm \text { SD }\end{array}$ \\
\hline & $\mathrm{P}=42.0 \pm 0.5 \mathrm{a}$ & $\mathrm{P}=0.53 \pm 0.05 \mathrm{a}$ & $\mathrm{P}=35.4 \pm 2.5 \mathrm{~b}$ & $\mathrm{P}=39.1 \pm 1.1 \mathrm{a}$ \\
\hline Barra do Bugres & $\mathrm{A}=45.2 \pm 4.6 \mathrm{a}$ & $\mathrm{A}=0.56 \pm 0.05 \mathrm{a}$ & $\mathrm{A}=41.5 \pm 2.7 \mathrm{a}$ & $\mathrm{A}=37.7 \pm 1.7 \mathrm{a}$ \\
\hline \multirow{2}{*}{ Peixoto Azevedo } & $\mathrm{P}=37.0 \pm 0.4 \mathrm{~b}$ & $\mathrm{P}=0.24 \pm 0.02 \mathrm{a}$ & $\mathrm{P}=33.4 \pm 0.2 \mathrm{~b}$ & $\mathrm{P}=35.8 \pm 0.3 \mathrm{~b}$ \\
& $\mathrm{~A}=42.6 \pm 1.6 \mathrm{a}$ & $\mathrm{A}=0.23 \pm 0.03 \mathrm{a}$ & $\mathrm{A}=39.5 \pm 0.8 \mathrm{a}$ & $\mathrm{A}=37.5 \pm 0.5 \mathrm{a}$ \\
\hline Porto Estrela (P1) & $\mathrm{P}=33.2 \pm 0.4 \mathrm{~b}$ & $\mathrm{P}=0.25 \pm 0.01 \mathrm{a}$ & $\mathrm{P}=28.7 \pm 0.3 \mathrm{~b}$ & $\mathrm{P}=31.4 \pm 0.4 \mathrm{~b}$ \\
\hline Porto Estrela $(\mathrm{P} 2)$ & $\mathrm{A}=38.5 \pm 0.4 \mathrm{a}$ & $\mathrm{A}=0.28 \pm 0.03 \mathrm{a}$ & $\mathrm{A}=34.7 \pm 0.7 \mathrm{a}$ & $\mathrm{A}=33.1 \pm 0.3 \mathrm{a}$ \\
\hline Santo Afonso & $\mathrm{P}=31.8 \pm 0.2 \mathrm{~b}$ & $\mathrm{P}=0.26 \pm 0.01 \mathrm{a}$ & $\mathrm{P}=29.1 \pm 0.9 \mathrm{~b}$ & $\mathrm{P}=31.5 \pm 0.9 \mathrm{a}$ \\
& $\mathrm{A}=38.5 \pm 1.2 \mathrm{a}$ & $\mathrm{A}=0.28 \pm 0.03 \mathrm{a}$ & $\mathrm{A}=34.4 \pm 0.6 \mathrm{a}$ & $\mathrm{A}=33.0 \pm 0.6 \mathrm{a}$ \\
\hline
\end{tabular}

FH: Flower height; FIH: filament insertion height; StH: stamen height; SSH: style/stigma height. P: pre-anthesis; A: anthesis. Means followed by the same letter in a column, did not differ from each other statistically within each population, by the Scott-Knott test at 5\% probability. P1: Population 1; P2: Population 2. ( $\mathrm{n}=20$ flowers). 
The size of the perianth of $H$. psittacorum differed statistically between the pre-anthesis and anthesis stages, except in the population of Barra do Bugres (Table 1).

The height of the filament insertion in the petal did not differ between the floral stages in all studied populations (Table 1). In population Porto Estrela (P2) and Santo Afonso, the style and stigma height did not differ statistically between the pre-anthesis and anthesis stages (Table 1); however, in all studied populations, the stamen was positioned above the stigma, confirming the herkogamy of the species (Table 1).

\section{Stigma receptivity and pollen viability}

The stigma receptivity in pre-anthesis varied from $20 \%$ to $80 \%$. In anthesis, $100 \%$ of the stigmas were receptive.
Pollen viability above $70 \%$ in pre-anthesis and anthesis was recorded in all studied populations with a variation of $70-80 \%$.

\section{Pollen tube growth}

Growth of pollen tubes was observed in different regions of the style of $H$. psittacorum (Figures 3A-I). In spontaneous self-pollinating treatments, callose plugs were observed near the basal area of the style (Figure 3C). The pollen tubes grew to the median region of the style in geitonogamy treatments (Figure 3D) with reduction of the presence of callose plugs in the basal area of the style (Figures 3E-F). In cross-pollinated treatments, the plugs were observed up to the basal area of the style (Figures 3G-I).

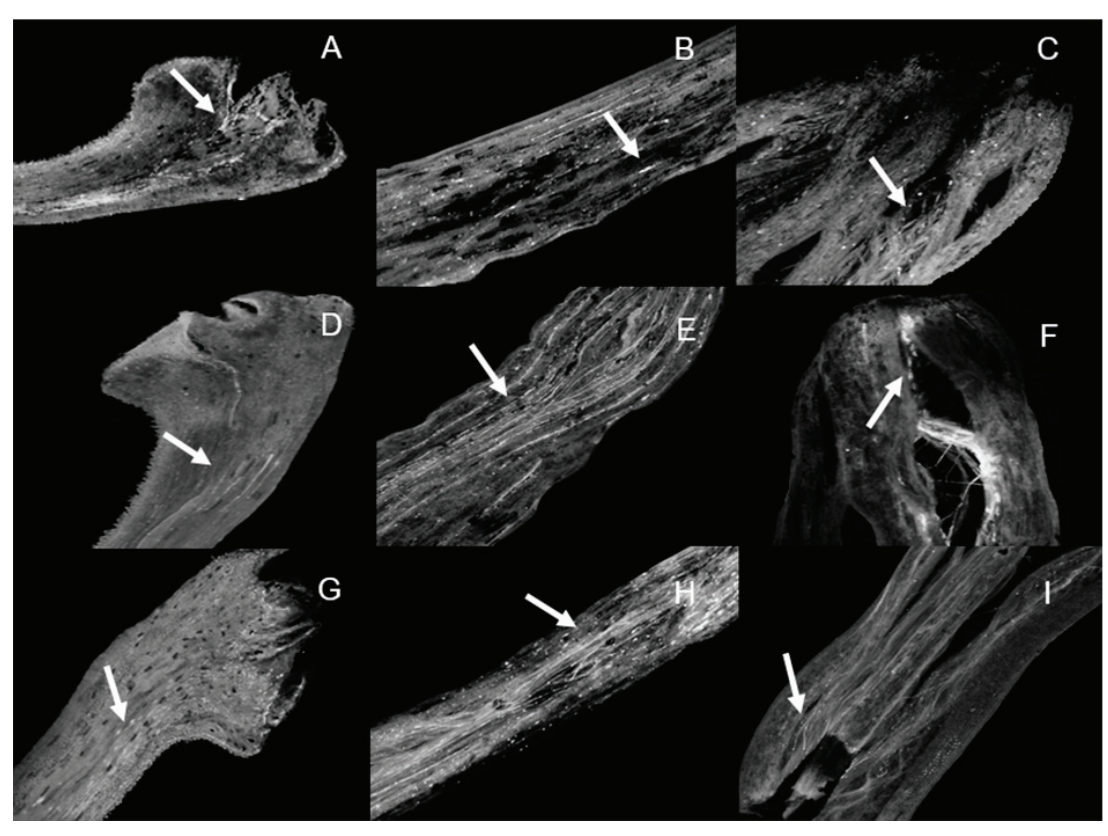

Figure 3. Growth of pollen tube after spontaneous self-pollination (A, B and C), in geitonogamy (D, E and F) and after cross-pollination $(\mathrm{G}, \mathrm{H}$ and $\mathrm{I})$. A, D and G- stigma region. B, E and Hmedian style region. C, F and I - basal style region.

The treatments of spontaneous self-pollination, geitonogamy and in vivo cross-pollination did not result in fruit formation.

Although the number of flowers per inflorescence varied largely among the populations (from a mean of $13.80 \pm 4.09$ in the population of Barra do Bugres to $51.80 \pm 24.69$ in the population of Peixoto de Azevedo), the number of fruits derived from natural pollinations, recorded in three of the five evaluated populations, was considered low (Table 2), and agrees with pollen tube growth data, suggesting that the main form of $H$. psittacorum reproduction in the study genotypes is related to asexual reproduction. 
Table 2. Flower and fruit production (mean $\pm \mathrm{SD}$ ) resulting from natural pollination of Heliconia psittacorum.

\begin{tabular}{|c|c|c|c|c|}
\hline Sampling sites & $\begin{array}{l}\mathbf{N}^{\circ} \text {. bracts } \\
\quad \pm \text { SD }\end{array}$ & $\begin{array}{c}\mathrm{N}^{0} \text {. flowers per bract } \\
\pm \mathrm{SD}\end{array}$ & $\begin{array}{c}\mathbf{N}^{0} \text {. flowers per } \\
\text { inflorescence } \\
\pm \mathrm{SD}\end{array}$ & $\begin{array}{c}\text { Fruiting percentage } \\
(\%)\end{array}$ \\
\hline Barra do Bugres & $3.60 \pm 0.55$ & $3.77 \pm 0.62$ & $13.80 \pm 4.09$ & $0.00 \pm 0.00$ \\
\hline Peixoto Azevedo & $5.80 \pm 0.84$ & $8.62 \pm 3.32$ & $51.80 \pm 24.69$ & $2.11 \pm 1.34$ \\
\hline Porto Estrela (P1) & $5.40 \pm 0.55$ & $8.06 \pm 2.24$ & $42.80 \pm 9.42$ & $3.30 \pm 3.12$ \\
\hline Porto Estrela (P2) & $5.20 \pm 0.45$ & $4.68 \pm 0.99$ & $24.20 \pm 4.55$ & $0.00 \pm 0.00$ \\
\hline \multirow[t]{2}{*}{ Santo Afonso } & $6.60 \pm 0.55$ & $6.68 \pm 1.83$ & $44.80 \pm 13.52$ & $3.51 \pm 1.30$ \\
\hline & $5.32 \pm 0.58$ & $6.36 \pm 1.8$ & $35.48 \pm 11.25$ & $1.78 \pm 1.15$ \\
\hline
\end{tabular}

P1: Population 1; P2: Population 2.

\section{DISCUSSION}

Despite the variation in the time of onset of floral anthesis, in all studied populations the flowers lasted one day, similar to the results found for other Heliconiaceae species (CRUZ et al., 2006; MISSAGIA and VERÇOZA, 2011). The beginning of anthesis before daybreak suggests pollination by nocturnal agents (KRESS, 1985). The positioning of the stamens above the stigma, pollen viability and stigma receptivity during anthesis of $H$. psittacorum flowers may favor self-pollination.

Aside from being taxonomically important, the ecological relevance of secondary pollen presentation is great, for arranging the pollen more effectively for pollinators. The red or orange colors of the bracts, secretion of nectar, stamens and stylus exerted on the tube of the corolla are characteristics of adaptation of pollination by hummingbirds (VAN DER PIJL, 1982).

In this sense, the pollen produced in the anthers is transferred to other floral structures such as filament, style or petals, where it is usually retained by specialized structures such as papillae or hairs (YEO, 1993). Secondary pollen presentation has been reported in families of Apocynaceae (ARAÚJO et al., 2011), Rubiaceae (AMORIM and OLIVEIRA, 2006) and Asteraceae (ROQUE and BAUTISTA, 2008; ERBAR and LEINS, 2015).

The presence of hairs on the style, as observed in all $H$. psittacorum populations, favors retention of pollen grains. Although not observed in this study, there is evidence for the presence of thread-like structures attached to the pollen wall of Heliconiaceae (ANDERSSON, 1981; ROSE and BARTHLOTT, 1995). In this way, the pollen grain attached to the strands have a function in the pollination biology, where large amounts of aggregate pollen can be transferred to the body of pollinators, increasing the likelihood of successful pollination (ROSE and BARTHLOTT, 1995). In Campanulaceae, interactions between stylar hairs and floral visitors increase the effectiveness of pollen capture, transfer and deposition (VRANKEN et al., 2014).

The reduced number of pollen tubes that reached the basal area of the style of the H. psittacorum flower suggests the existence of incompatibility sites in the treatments of spontaneous self-pollination, geitonogamy and crosspollination. Different sites of growth inhibition of pollen tubes with problems of syngamy and embryo abortion were registered in neotropical Heliconia species of Costa Rica, where the barriers of cross-pollination act as a mechanism to prevent hybridization between sympatric species (KRESS, 1983), different sites of incompatibility along the style were recorded in H. solomonensis (KRESS, 1985) and H. bihai (MELÉNDEZ-ACKERMAN et al., 2008).

The absence of fruiting after manual in vivo pollination treatments in natural $H$. psittacorum populations was similar to that reported by Lee et al. (1994) after spontaneous self-pollination and cross-pollination in six $H$. psittacorum cultivars and by Missagia and Verçoza (2011) after spontaneous self-pollination of $H$. spathocircinata.

The low percentages or absence of fruiting resulting from natural pollination recorded in the $H$. psittacorum populations were similar to those observed in $H$. acuminata (BRUNA et al., 2004), where the mean fruit yield was lower than that found in this study (mean 0.30 $\pm 0.24)$. The low production of Heliconiaceae fruits is attributed to factors such as nutrient-poor soils (BRUNA et al., 2002), limitation of pollinator visits (BRUNA et al., 2004), and restricted energy resources in nectar (BLOOM et al., 1985).

Under pollinator scarcity or pollen limitation, vegetative propagation may be the only way to preserve Heliconiaceae species, although the possible costs of this type of reproduction should be considered.

\section{CONCLUSIONS}

- Floral herkogamy are observed in anthesis and the positioning of the stamens above the stigma, pollen viability and stigma receptivity during anthesis of $H$. psittacorum flowers may favor self-pollination.-

- Pollen transfer to the adhered hairs in the stylar region was clearly observed during anthesis, constituting the first record of occurrence of secondary pollen presentation in Heliconiaceae. 
- Pollen germination were observed with self-pollination, geitonogamy, cross-pollination and natural pollination nevertheless the pollen tube growth was inhibited in the stigmatic, style and basal regions of the pistil.

- Due to low fruiting rate in controlled and natural pollinations, our results suggest that the main reproduction form of $H$. psittacorum in the study areas is based on asexual reproduction.

\section{ACKNOWLEDGEMENTS}

The authors thank the National Council for Scientific and Technological Development (CNPq) for grant no. 444017/2014-3, and the students of botany and breeding at the Universidade do Estado de Mato Grosso -UNEMAT, Campus Tangará da Serra, Brazil, for their helpful contribution in the laboratory.

\section{AUTHOR CONTRIBUTION}

T.O.N. (D0000-0002-8353-1610: field analysis, data collection and analysis, manuscript preparation and review. P.C.S. (D) 0000-0002-5893-6210: data collection and analysis, V.L. (D0000-0001${ }^{9948-9501}$ : data analysis and interpretation, manuscript review. S.M. (D0000-0003-4007-3100: data collection and analysis, W.K. (D) 0000-0002-5308-7715: data analysis and interpretation, manuscript review. C.A.S. D0000-0001-7898-7931: data analysis and interpretation, manuscript preparation and review.

\section{REFERENCES}

AMORIM, F.W.; OLIVEIRA, P.E. Estrutura sexual e ecologia reprodutiva de Amaioua guianensis Aubl. (Rubiaceae), uma espécie dióica de formações florestais de cerrado. Revista Brasileira de Botânica, v.29, p.353-362, 2006. DOI: http://dx.doi.org/10.1590/S010084042006000300003

ANDERSSON, L. Revision of Heliconia sect. Heliconia (Musaceae). Nordic Journal of Botany, v.1, p.759-784, 1981. DOI: https://doi.org/10.1111/j.1756-1051.1981. tb01163.x

ARAÚJO, L.D.A.; QUIRINO, Z.G.M.; MACHADO, I.C. Fenologia reprodutiva, biologia floral e polinização de Allamanda blanchetti, uma apocynaceae endêmica da Caatinga. Revista Brasileira de Botânica, v.24, p.211-222, 2011. DOI: http://dx.doi.org/10.1590/S010084042011000200008

BLOOM, A.J.; CHAPIN, F.S.; MOONEY, H.A. Resource limitation in plants: an economic analogy. Annual Review of Ecology and Systematics, v.16, p.363-392, 1985. DOI: https://doi.org/10.1146/annurev.es.16.110185.002051

BRAGA, J.M.A. Heliconiaceae. Lista de Espécies da Flora do Brasil. Jardim Botânico do Rio de Janeiro. Available in: <http://floradobrasil.jbrj.gov.br/>. Accessed on: 10 September, 2016.
BRUNA, E.M.; KRESS, W.J.; MARQUES, F.; SILVA, O.F. Heliconia acuminata reproductive success is independent of local floral density. Acta Amazonica, v.34, p.467-471, 2004. DOI: http://dx.doi.org/10.1590/S004459672004000300012

BRUNA, E.M.; NARDY, O.; STRAUSS, S.Y.; HARRISON, S.P. Experimental assessment of Heliconia acuminata growth in a fragmented Amazonian landscape. Journal of Ecology, v.90, p.639-649, 2002. DOI: https:// doi.org/10.1046/j.1365-2745.2002.00707.x

CASTRO, C.E.F.; GONÇALVES, C.; MOREIRA, S.R.; FARIA, O.A. Helicônias brasileiras: características, ocorrência e usos. Revista Brasileira de Horticultura Ornamental, v.17, p. 5-24, 2011. DOI: https://doi. org/10.14295/rbho.v17i1.725

CASTRO, S.; SILVEIRA, P.; NAVARRO, L. How does secondary pollen presentation affect the fitness of Polygala vayredae (Polygalaceae)? American Journal of Botany, v.95, p.706-712, 2008. DOI: 10.3732/ajb.2007329

COSTA, F.R.C.; ESPINELLI, F.P.; FIGUEIREDO, F.O.G. Guide to the Zingiberales of PPBio sites in Brazillian Western Amazonia. Manaus: Áttema Design Editorial, 2011. 284p.

CRUZ, D.D.; MELLO, M.A.R.; SLUYS, M.V. Phenology and floral visitors of two sympatric Heliconia species in the Brazillian Atlantc forest. Flora, v.201, p.519-527, 2006. DOI: 10.1016/j.flora.2005.12.001

DALLACORT, R.; MARTINS, J.A.; INOUE, M.H.; FREITAS, P.S.L.; COLETTI, A.J. Distribuição das chuvas no município de Tangará da Serra, médio norte do Estado de Mato Grosso, Brasil. Acta Scientiarum. Agronomy, v.33, p.193-200, 2011. DOI: 10.4025/actasciagron.v33i2.5838

EMBRAPA. Sistema brasileiro de classificação de solos. Rio de Janeiro: Embrapa solos, 2006.

ENDRESS, P.K. Diversity and Evolutionary Biology of tropical flowers. Cambridge: Cambridge University Press, 1994. 420p. DOI: https://doi.org/10.1016/S01695347(00)89041-2

ERBAR, C.; LEINS P. Diversity of styles and mechanisms of secondary pollen presentation in basal Asteraceae-New insights in phylogeny and function. Flora, v.217, p.109-130, 2015. DOI: http://dx.doi.org/10.1016/j.flora.2015.10.002

GANON, D.G.; KORMANN, U.G.; HADLEY, A.; BETTS, M.G.; JONES, F.A. The "jack-in-the-box" stamens of Heliconia wagneriana (Heliconiaceae). Ecology, v.99, p.488-490, 2017. DOI. https://doi.org/10.1002/ecy.2042. 
KEARNS, C.A.; INOUYE, D. Techniques for pollinations biologists. Niwot: University Press of Colorado, 1993. 579 p.

KRESS, W.J. Bat pollination of na old world Heliconia. Biotropica, v.17, p.302-308, 1985. DOI: $10.2307 / 2388592$

KRESS, W.J. Crossability Barriers in Neotropical Heliconia. Annals of Botany, v.52, n.2, p.131-147, 1983. DOI: https://doi.org/10.1093/oxfordjournals.aob.a086559

LADD, P.G. Pollen presenters in the flowering plants - form and function. Botanical Journal of the Linnean Society, v.115, p.165-195, 1994. DOI: https://doi.org/10.1006/ boj1.1994.1040

LEE, Y.H.; NG, N.Y.; GOH, C.J. Pollen formation and fruit set in some cultivars of Heliconia psittacorum. Scientia Horticulturae, v.60, p.167-172, 1994. DOI: https://doi. org/10.1016/0304-4238(94)90072-8

LEINS, P.; ERBAR, C. Flower and Fruit. Morphology, Ontogeny, Phylogeny, Function and Ecology. Stuttgart: Schweizerbart Science Publishers, 2010. 439p.

LLOYD, D.G.; YATES, J.M. Intrasexual Selection and the segregation of pollen and stigmas in hermaphrodite plants, exemplified by Wahlenbergia albomarginata (Campanulaceae). Evolution, v.5, p.903-913, 1982. DOI: 10.1111/j.1558-5646.1982.tb05462.X

MARTIN, F.W. Staining and observing pollen tubes in the style by means of fluorescence. Stain Techniques, v.34, p.115-128, 1959. DOI: https://doi. org/10.3109/10520295909114663

MELÉNDEZ-ACKERMAN, E.; ROJAS-SANDOVAL, J.; PLANAS, S. Self-compatibility of microgametophytes in Heliconia bihai (Heliconeacea) from St. Lucia. Caribbean Journal of Science, v.44, p.145-149, 2008. DOI: https:// doi.org/10.18475/cjos.v44i2.a3
MISSAGIA, C.C.C.; VERÇOZA, F.C. Fenologia reprodutiva, polinização e frutificação de Heliconia spathorcircinata Aristeg. (Heliconiaceae) em fragmento de Floresta Atlântica do município do Rio de Janeiro. Revista Biotemas, v.24, p.13-23, 2011. DOI: $10.5007 / 2175-7925.2011 \mathrm{v} 24 \mathrm{n} 3 \mathrm{p} 13$

R Development Core Team. R: A language and environment for statistical computing. R Foundation for Statistical Computing, Vienna, Austria. ISBN 3-90005107-0, 2014.

ROQUE, N.; BAUTISTA, H. Asteraceae: Caracterização e Morfologia Floral. Salvador: EDUFBA, 2008. 73p.

ROSE, M. J.; BARTHLOTT, W. Pollen-connecting threads in Heliconia (Heliconiaceae). Plant Systematics and Evolution, v.195, p.61-65, 1995.

SOUZA, E.B.; COSTA, C.B.N.; BORBA, E.L. Ocorrência de auto-incompatibilidade homomórfica em Mitracarpus longicalyx E. B. Souza \& M. F. Sales (Rubiaceae Spermacoceae). Revista Brasileira de Botânica, v.30, p.281-287, 2007. DOI: http://dx.doi.org/10.1590/S010084042007000200012

VAN DER PIJL, L. Principles of dispersal in higher plants. 3ed. Berlin: Springer-Verlag, 1982. 212p.

VRANKEN, S.; BRYS, R.; HOFFMANN, M.; JACQUEMYN, H. Secondary pollen presentation and the temporal dynamics of stylar hair retraction and style elongation in Campanula trachelium (Campanulaceae). Plant Biology, v.16, p.669-676, 2014. DOI: 10.1111/plb.12097.

WANG, F.; ZHANG, F-J.; CHEN, F-D.; FANG, W-M.; TENG, N-J. Identification of Chrysanthemum (Chrysanthemum morifolium) Self-Incompatibility. The Scientific World Journal, v.1, p.1-9, 2014. DOI: http:// dx.doi.org/10.1155/2014/625658

YEO, P.F. Secondary pollen presentation: form, function, and evolution. Wien: Springer-Verlag, 1993. 259p. 